\title{
COMENTÁrio AO ARTIGO "NiETZSCHE Y EL DEVENIR VITAL: DE LO INORGÁNICO A LO ORGÂNICO”
}

\author{
Márcio José Silveira Lima ${ }^{1}$
}

Referência do texto comentado: MARTÍNEZ BECERRA, Pablo. Nietzsche y el devenir vital: de lo inorgánico a lo orgánico. Trans/Form/Açáo: revista de filosofia da Unesp, vol. 43, n. 4, p. 283 - 308, 2020.

Em seu artigo "Nietzsche y el devenir vital: de lo inorgánico a lo orgânico", Pablo Martínez Becerra dedica-se a uma das teorias mais difíceis e estudadas de Nietzsche, a da vontade de potência ${ }^{2}$, dando ênfase a aspectos nem sempre explorados, como as consideraçóes do filósofo sobre o caráter inorgânico do mundo. Destacando o contexto das leituras que foram importantes e que possivelmente influenciaram a elaboração da doutrina, o autor demarca o lugar do nome mais conhecido e respeitado entre os nomes que influenciaram Nietzsche: o de Schopenhauer. A seu ver, acertadamente nos parece, a filosofia da vontade poderia ser considerada como modelo de inspiração apenas para uma parte da teoria da vontade de potência, uma vez que ela não considera o mundo como vontade, em sua expressão inorgânica. Para expandir o âmbito de atuação a todo o real, as leituras "científicas" teriam tido um papel importante, tais como Zöllner, Boscovich, Vogt, Spir, Kopp.

A favor da tese de Martínez Becerra, conta o principal texto publicado por Nietzsche sobre a vontade de potência: o parágrafo 36 de Além do bem e do mal (NIETZSCHE, JGB, 1988, KSA 5.55). Ali, na condensada apresentação

\footnotetext{
${ }^{1}$ Professor de Filosofia da Universidade Federal do Sul da Bahia - UFSB - e Editor Responsável dos Cadernos Nietzsche. (iD https://orcid.org/0000-0001-6813-8864. E-mail: marscill@gmail.com. Itabuna, BA, Brasil.

2 O termo alemão Wille zur macht tem sido traduzido, no Brasil, tanto por "vontade de poder" (preferência do autor, em castelhano), quanto por "vontade de potência", que é o de nossa escolha.
} 
da teoria, entre as muitas teses, afirma-se que o mundo, visto de dentro, em seu caráter inteligível, é vontade de potência e nada além. O primeiro aspecto dessa concepção, como Martínez Becerra mostra, é que a crítica de Nietzsche ao mecanicismo e seu princípio de conservação consiste em rejeitar que os seres inorgânicos sejam definidos em termos de um substratum material inerte, defendendo, com a teoria da vontade de potência, que atuam de acordo com a mesma relação de forças e de expansão que os seres orgânicos.

Não há, portanto, uma delimitação daquilo que é próprio da vontade de potência ao mundo orgânico. Contudo, a não restriçấo da vontade de potência ao mundo orgânico leva o autor a questionar se Nietzsche seria adepto de um hylozoísmo. Ainda que não mencione a famosa passagem de Zaratustra (NIETZSCHE, ZA II, Da superação de si, 1988, KSA 4.149), em que o personagem afirma ter encontrado vida onde encontrou vontade de potência, essa ideia parece conduzir, no artigo, a uma identificação entre a vontade de potência como forma de todo ser a um princípio vitalista. E essa associação parece problemática. Se toda vida implica uma expressão da vontade de potência, isso náo significa que toda a vontade de potência seja caracterizada por um princípio vital. Nesse caso, não há como concluir que haja uma atividade vital nos seres inorgânicos. Além disso, o próprio Nietzsche, num conhecido texto de $A$ gaia ciência, o aforismo 109, alerta para que nos guardemos de pensar o mundo como um ser vivo (NIETZSCHE, FW, 1988, KSA 3.552).

Citando um fragmento de Nietzsche em que o mundo inorgânico é governado pela vontade de potência, e no qual o filósofo acrescenta, corrigindo-se, que não existe mundo inorgânico, Martínez Becerra retira da passagem a conclusão de que o inorgânico é também vida. Ora, a passagem, em si mesma, é daqueles textos do filósofo em que há contraste com outros, nas quais ele faz uma diferenciação entre orgânico e inorgânico (o artigo mesmo traz esses textos contrastantes). Além disso, embora se considere a recusa do fragmento em negar essa diferença, não há como concluir que o inorgânico seja constituído pela vida. Ora, como realça Martínez Becerra, em outras passagens, é possível encontrar outras formas de atuar que sejam comuns tanto à vida orgânica quanto à inorgânica, as quais seriam próprias da vontade de potência, como uma óptica de percepção, a qual está amparada pelos textos do próprio filósofo. Nesse caso, e como o artigo nos informa, Nietzsche por vezes atribui uma superioridade ao mundo inorgânico, considerando que a vida constitui um "acidente" e uma "exceçáo". Se se trata de atribuir um possível 
hylozoísmo a Nietzsche, porque haveria um vitalismo irrestrito da vontade de potência, ainda que o artigo não assuma esse ponto de vista de modo explícito, parece que há elementos mais consistentes para negar essa possibilidade, e que o próprio texto parece mostrar, na maioria das vezes.

\section{REFERÊNCIA}

NIETZSCHE, Friedrich. Sämtliche Werke. Kritische Studienausgabe (KSA), 15 vols. (Organizada por Giorgio Colli e Mazzino Montinari), Berlim: Walter de Gruyter \& Co., 1988. 
LIMA, M. J. S.

Recebido: $22 / 10 / 2020$

Aceito: 25/10/2020 